\title{
Effect of Salts Stress on the Growth and Yield of Wheat (Triticum aestivum L.)
}

\author{
Niaz Ahmed Kalhoro', Inayatullah Rajpar ${ }^{2}$, Shahmir Ali Kalhoro ${ }^{3,4}$, Amjad Ali ${ }^{5}$, Sajjad Raza \\ Muneer Ahmed ${ }^{3,5}$, Fahad Ali Kalhoro6, Muhammad Ramzan33, Fazli Wahid ${ }^{7}$
}

${ }^{1}$ Soil Survey of Pakistan, Devolution Cell, Cabinet Division, Camp Office, Hyderabad, Pakistan

${ }^{2}$ Department of Soil Science, Sindh Agriculture University, Tando Jam, Pakistan

${ }^{3}$ Faculty of Agriculture, Lasbela University of Agriculture, Water and Marine Sciences, Balochistan, Pakistan

${ }^{4}$ Institute of Soil and Water Conservation, Northwest A\& F University, Yangling, China

${ }^{5}$ College of Natural Resources \& Environment, Northwest A\&F University, Yangling, China

${ }^{6}$ Department of Plant Breeding and Genetics, Sindh Agriculture University, Tando Jam, Pakistan

${ }^{7}$ Department of Plant Production and Technologies, Faculty of Agricultural Science and Technology, Omer Halisdemir University,

Nigde, Turkey

Email: amjadali@aup.edu.pk

How to cite this paper: Kalhoro, N.A., Rajpar, I., Kalhoro, S.A., Ali, A., Raza, S., Ahmed, M., Kalhoro, F.A., Ramzan, M. and Wahid, F. (2016) Effect of Salts Stress on the Growth and Yield of Wheat (Triticum aestivum L.). American Journal of Plant Sciences, 7, 2257-2271.

http://dx.doi.org/10.4236/ajps.2016.715199

Received: September 18, 2016

Accepted: November 11, 2016

Published: November 14, 2016

Copyright $\odot 2016$ by authors and Scientific Research Publishing Inc. This work is licensed under the Creative Commons Attribution International License (CC BY 4.0)

http://creativecommons.org/licenses/by/4.0/

\section{Abstract}

In order to study the effect of salts stress on the growth and yield of wheat (cv. Inqalab), a pot experiment was conducted in the wire-house of the Department of Soil Science, Sindh Agriculture University Tando Jam. The soil was artificially salinized to a range of salinity levels i.e. EC $2.16,4.0,6.0,8.0$ and $10.0 \mathrm{dS} \cdot \mathrm{m}^{-1}$ with different salts $\left(\mathrm{MgCl}_{2}+\mathrm{CaCl}_{2}+\mathrm{Na}_{2} \mathrm{SO}_{4}\right)$. The salinized soil used for the experiment was sandy clay in texture, alkaline in reaction $(\mathrm{pH}>7.0)$ and moderate in organic matter $(0.95 \%)$ content. The results showed that with increasing salinity there was an increase in the ECe, $\mathrm{Na}^{+}, \mathrm{Ca}^{2+}, \mathrm{Mg}^{2+}$ and $\mathrm{Cl}^{-}$and decrease in the $\mathrm{K}^{+}$, SAR and ESP values of the soil Increasing salinity, progressively decreased plant height, spike length, number of spikelets spike ${ }^{-1} 1000$ grain weight and yield (straw and grain). Adverse effects of salts on plants were associated with the accumulation of less $\mathrm{K}^{+}$and more $\mathrm{Na}^{+}$and $\mathrm{Cl}^{-}$in their flag leaf sap, grains and straw. This resulted in lower $\mathrm{K}^{+}: 5 \mathrm{Na}^{+}$ratio in flag leaf sap, grains and straw of wheat plants. These results indicated that the effects of salts stress were greater at 10 than at 8,6 and $4 \mathrm{EC} \mathrm{dS} \cdot \mathrm{m}^{-1}$.

\section{Keywords}

Salinity, Tolerance, Effect, Yield, Wheat

\section{Introduction}

Wheat (Triticum aestivum L.) is an important cereal crop of the world. It is one of the 
staple foods for more than one third of the world population. Wheat played a vital role in the development of civilization. The king of cereals wheat is the principal source of food and is extensively grown, consumed and preferred in Pakistan. It contains approximately $60 \%-80 \%$ protein, $2 \%-2.5 \%$ glucose, $1.5 \%-2 \%$ fat and $2 \%-3 \%$ mineral matter [1]. However, these may vary in proportion from variety to variety and locality to locality. Wheat crop is cultivated in all provinces of Pakistan as a bumper winter crop. The average yield of wheat in Pakistan is about $23888 \mathrm{~kg} \cdot \mathrm{ha}^{-1}$ which is comparatively very low to the other wheat growing countries of the world. The factors behind the low yield include poor fertility status of soil, less and imbalance use of fertilizers, unawareness and utilization of modern technology by the farmers, environment and climatic condition of the area, deficiency of macro and micronutrients and availability of required irrigation water at proper time [2].

Besides the above factors, soil salinity is the major problem, which affects the yield of this important crop. It is commonly observed in arid and semi-arid regions of the world [3]. It is considered as a serious soil problem of Pakistan. About $6.3 \mathrm{~m}$ ha land is affected by salinity. Whereas in Sindh $2.3 \mathrm{~m}$ ha land is affected by different types of salts, mostly slats of chlorides and sulfates of sodium, calcium and magnesium [4]. The soil which contains inorganic salts, also supplies necessary nutrients to the plant but when the concentration of these salts reaches such a level that is harmful for plant growth [5].

Excess amount of salts in the soil affects plant from germination to harvesting [6]. It may affect the plants in two ways: a) by decreasing the rate of water entry in to plants, b) promoting the entry of toxic ions [7]. Generally, salinity problem increase with increasing salt concentration in irrigation water. Crop growth reduction due to salinity is generally related to the osmotic potential of the root-zone soil solution. This will lead to certain physiological changes and substantial reduction in crop production [8]. Plants in salt stress condition require a tight nutrition dose to maintain their normal physiology and to face the condition were they locate. In these circumstances they require a balanced nutrition of both macro and micronutrient elements to boost up their growth and development. Generally macronutrients N, P, K are supplied extensively but micronutrients are often ignored. However, their essentiality cannot be neglected for better crop yield especially under tough conditions.

The relative salt tolerance of wheat crop is $7.0 \mathrm{dS} \cdot \mathrm{m}^{-1}$ and its yield decrease is $25 \%$ at $9.0 \mathrm{dS} \cdot \mathrm{m}^{-1}$ [9]. The reduction in growth and yield varies between cultivars and salt concentrations of the medium [10]. The recently developed cultivars form a much diversed genetic base and may therefore possess a wider range of salts stress tolerance. Keeping in view the above facts, this study was planned to see the growth and yield response of Inqalab wheat variety to salts $\left(\mathrm{MgCl}_{2}+\mathrm{CaCl}_{2}+\mathrm{Na}_{2} \mathrm{SO}_{4}\right)$ stress.

\section{Materials and Methods}

In order to assess the effect of salts stress on the growth and yield of wheat variety Inqabab, a pot experiment was conducted in the wire-house of the Department of Soil Science, Sindh Agriculture University Tando Jam. The following methodology was 
adopted.

\subsection{Experimental Design}

Fertile soil (plough layer) was collected from the arable land of latif Experimental Farm of Sindh Agriculture University, Tando Jam. The soil was air dried ground and passed through $4 \mathrm{~mm}$ garden sieve. The air dried soil was placed in plastic containers with drainage holes in bottom. The $9 \mathrm{~kg}$ pots were arranged on wooden benches in RCBD with three replications.

\subsection{Seed Sowing, Fertilizer and Irrigation}

Seeds of wheat variety Inqalab were at $4 \mathrm{~cm}$ plant to plant distance. Few days after emergence, 7 seedlings were allowed to grow in each pot up to maturity. In order to reduce losses by evapotranspiration, the pots were regularly irrigated by normal irrigation water. The recommended does of NPK was applied in the form of NPK (10:23:15) and urea $(46 \% \mathrm{~N})$ to each pot. Nitrogen was applied at the rate $136 \mathrm{~kg} \mathrm{~N} \mathrm{ha}^{-1}$ in the form of NPK and urea in three splits, first at the time of sowing, second at the $1^{\text {st }}$ irrigation and the remaining at the $2^{\text {nd }}$ irrigation. Phosphorus and $\mathrm{K}$ were applied at the rate $67 \mathrm{~kg} \mathrm{P}_{2} \mathrm{O}_{5}^{-} \mathrm{ha}^{-1}$ and $44 \mathrm{~kg} \mathrm{~K}_{2} \mathrm{O} \mathrm{ha}{ }^{-1}$ in the form of NPK at the time of sowing.

\subsection{Preparation of Saline Soil}

Different saline soil treatments were prepared artificially by mixing different salts. The quantity of different salts $\left(\mathrm{MgCl}_{2}, \mathrm{CaCl}_{2}\right.$ and $\left.\mathrm{Na}_{2} \mathrm{SO}_{4}\right)$ required for the preparation of saline soil treatments was calculated using the method described by Rowell [11]. The salinity levels developed for the experiment were:

$$
\begin{aligned}
& \text { T1 (control) } 2.16\left(\mathrm{dS} \cdot \mathrm{m}^{-1}\right) \text { (Non-saline); } \\
& \text { T2 }\left(\mathrm{MgCl}_{2}+\mathrm{CaCl}_{2}+\mathrm{Na}_{2} \mathrm{SO}_{4}\right) 4.0\left(\mathrm{dS} \cdot \mathrm{m}^{-1}\right)(\text { Saline); } \\
& \text { T3 }\left(\mathrm{MgCl}_{2}+\mathrm{CaCl}_{2}+\mathrm{Na}_{2} \mathrm{SO}_{4}\right) 6.0\left(\mathrm{dS} \cdot \mathrm{m}^{-1}\right) \text { (Slightly saline); } \\
& \text { T4 }\left(\mathrm{MgCl}_{2}+\mathrm{CaCl}_{2}+\mathrm{Na}_{2} \mathrm{SO}_{4}\right) 8.0\left(\mathrm{dS} \cdot \mathrm{m}^{-1}\right) \text { (Moderately saline); } \\
& \text { T5 }\left(\mathrm{MgCl}_{2}+\mathrm{CaCl}_{2}+\mathrm{Na}_{2} \mathrm{SO}_{4}\right) 10\left(\mathrm{dS} \cdot \mathrm{m}^{-1}\right) \text { (Highly saline). }
\end{aligned}
$$

\subsection{Agronomic Observations}

Following agronomic observations were recorded:

- Plant height $(\mathrm{cm})$,

- Spike length $(\mathrm{cm})$,

- Number of spikelet's spiket ${ }^{-1}$,

- Straw dry weight $\left(\mathrm{mg} \cdot\right.$ plant $\left.^{-1}\right)$,

- Grain yield (mg.plant ${ }^{-1}$ ),

- 1000 grain weight (g).

\subsection{Plant Analysis}

\subsubsection{Flag Leaf Sampling, Sap Extraction and Chemical Analysis}

The flag leaf of three plants from each replication of all the treatments was detached, 
placed in Eppendorf tubes and stored in a freezer at $-10^{\circ} \mathrm{C}$. The lamina of the flag leaves were removed and the sap was extracted and analyzed for $\mathrm{Na}^{+}, \mathrm{K}^{+}$using the method of Gorham [12]. $\mathrm{K}^{+} / \mathrm{Na}^{+}$ratio was also determined by using the values of $\mathrm{K}^{+}$and $\mathrm{Na}^{+}$(Table 1).

\subsubsection{Preparation of Straw and Grain Samples for Chemical Analysis}

Straw and grain samples from all the replications of each treatment were prepared for analysis of $\mathrm{Na}^{+}, \mathrm{K}^{+}, \mathrm{Ca}^{2+}$ and $\mathrm{Mag}^{2+}$.

\subsection{Soil Analysis}

The soil samples were collected before sowing from each treatment. Samples were prepared and analyzed for soil texture, $\mathrm{pH}, \mathrm{ECe}\left(\mathrm{dS} \cdot \mathrm{m}^{-1}\right), \mathrm{O} . \mathrm{M} \%$, cations $\left(\mathrm{Na}^{+}, \mathrm{K}^{+}, \mathrm{Ca}^{2+}\right.$ and $\left.\mathrm{Mg}^{2+}\right)$ and anions $\left(\mathrm{CO}_{3}^{2-}, \mathrm{HCO}_{3}^{-}\right.$and $\left.\mathrm{Cl}^{-}\right)$, Soil samples were also collected after harvest of the crop for the analysis of above properties with the exception of OM\% and soil texture (Table 2).

\subsection{Calculations}

Sodium adsorption ratio (SAR), exchangeable sodium ratio (ESR) and exchangeable sodium percentage (ESP) were calculated using the following formula suggested by Rowell [11].

- Sodium Adsorption Ratio (SAR) $=\left(\mathrm{Na}^{+}\right) /\left(\mathrm{Ca}^{2}+\mathrm{Mg}^{2+}\right) 1 / 2$,

- Exchangeable Sodium Ratio (ESR) $=-0.013+0.05 \mathrm{SAR}$,

- Exchangeable Sodium Percentage (ESP) $=100 \mathrm{ESR} /(1+\mathrm{ESR})$.

\subsection{Statistical Analysis}

All plant data were analysed by performing ONEWAY-ANOVA using Minitab-12 statistical package. Standard Error for Different between Means (S.E.D) was calculated using the following formula: $\mathrm{SED}=(2 \mathrm{EMS} / \mathrm{n})^{1} / 2$ Least Significant Different (LS.D.) $=$ S.E.D $\times$ edf $t$ value at $5 \%$ probability level.

\section{Results and Discussion}

\subsection{Soil Properties}

Physico-chemical properties of soil before sowing and after harvesting of wheat crop

Table 1. Plant analysis.

\begin{tabular}{clccc}
\hline S. No. & \multicolumn{1}{c}{ Determinations } & Method Used & Equipment used & References \\
\hline 1 & $\begin{array}{l}\text { Extraction of flag Leaf sap for } \\
\mathrm{Na}^{+} \text {and } \mathrm{K}^{+} \text {analysis }\end{array}$ & $\begin{array}{c}\text { Centrifuge } \\
\text { method }\end{array}$ & Eppendorf Tubes & Gorham [13] \\
& $\begin{array}{l}\text { Preparation and Analysis of } \\
\text { straw for } \mathrm{Na}^{+} \text {and } \mathrm{K}^{+}\end{array}$ & $\begin{array}{l}\text { Acid wet } \\
\text { digestion }\end{array}$ & $\begin{array}{c}\text { EEL-flame } \\
\text { photometer }\end{array}$ & Rowell [11] \\
& $\begin{array}{l}\text { Preparation and Analysis of } \\
\text { straw and grain samples for } \mathrm{Cl}^{-}\end{array}$ & $\begin{array}{l}\text { Dry ash } \\
\text { method }\end{array}$ & Muffle Furnace & $\begin{array}{c}\text { Methods Manuals } \\
\text { Soils [14] }\end{array}$ \\
\hline
\end{tabular}


Table 2. Soil analysis.

\begin{tabular}{|c|c|c|c|c|}
\hline S. No. & Determinations & Method adopted & Equipment used & References \\
\hline 1 & Soil texture & Bouyoucos Hydrometer & Hydrometer & $\begin{array}{l}\text { Kanwar and } \\
\text { chopra [15] }\end{array}$ \\
\hline 2 & $\mathrm{ECe}\left(\mathrm{dS} \cdot \mathrm{m}^{-1}\right)$ & 1:2 soil water Extract & Digital EC Meter & Rowell [11] \\
\hline 3 & $\mathrm{pH}$ & 1:2 soil water Extract & Digital pH Meter & Rowell [11] \\
\hline 4 & O.M. (\%) & $\begin{array}{l}\text { Walkley Black Method No. } 9 \text { Titration } \\
\text { with } 0.5 \text { N Ferrous Solution }\end{array}$ & Burette & Jackson [16] \\
\hline 5 & $\begin{array}{l}\text { Soluble } \mathrm{Na}^{+} \\
\text {and } \mathrm{K}^{+}\end{array}$ & Method No. 10 and 11 & $\begin{array}{l}\text { EEL-flame } \\
\text { Photometer }\end{array}$ & $\begin{array}{l}\text { Handbook- } \\
60 \text { USSL [17] }\end{array}$ \\
\hline 6 & $\begin{array}{l}\text { Soluble } \mathrm{Ca}^{2+} \\
\text { and } \mathrm{Mg}^{2+}\end{array}$ & $\begin{array}{l}\text { Method No. } 7 \text { Titration with EDTA } \\
\text { solution (soil and plant (samples) }\end{array}$ & Burette & $\begin{array}{l}\text { Hand book- } \\
60 \text { USSL [17] }\end{array}$ \\
\hline 7 & $\mathrm{CO}_{3}^{2-}$ and $\mathrm{HCO}_{3}^{-}$ & $\begin{array}{l}\text { Method No. } 12 \text { Titration with Standard } \\
\mathrm{H}_{2} \mathrm{SO}_{4} \text { Solution (soil and plant samples) }\end{array}$ & Burette & $\begin{array}{l}\text { Hand book- } \\
60 \text { USSL [17] }\end{array}$ \\
\hline 8 & $\mathrm{Cl}^{-}$ & $\begin{array}{l}\text { Method No. } 13 \text { Titration with Standard } \\
\mathrm{AgNO}_{3} \text { Solution (soil and plant samples) }\end{array}$ & Burette & $\begin{array}{l}\text { Hand book- } \\
60 \text { USSL [17] }\end{array}$ \\
\hline
\end{tabular}

are summarized in Table 3 and Table 4 . the chemical properties of soil before sowing and after harvesting of wheat crop showed ECe, $\mathrm{pH}$ soluble cations and anions, SAE and ESP values were typical of that an agricultural soils of Sindh. However, when the same soil was treated with different proportions of $\mathrm{MgCl}_{2}, \mathrm{CaCl}_{2}$ and $\mathrm{Na}_{2} \mathrm{SO}_{4}$ salts that showed an increase in ECe and very small decrease in SAR and ESP. The pH of treated soil was alkaline in reaction before sowing and it decreased slightly in all treatments after harvest of the crop. With increasing concentrations of salts there was rise in $\mathrm{Na}^{+}$, $\mathrm{Ca}^{2+}, \mathrm{Mg}^{2+}$ and $\mathrm{Cl}^{-}$in all soil treatments. During the course of the experiment $\mathrm{pH}$ and soil salinity in almost all treatments $\left(\mathrm{T} 2=5.91, \mathrm{~T} 4=9.2\right.$ and $\left.\mathrm{T} 5=10.3 \mathrm{dS} \cdot \mathrm{m}^{-1}\right) \mathrm{de}-$ creased slightly possibly due to leaching and uptake of soluble salts by the plants.

\subsection{Effects of Salts Stress on Plant Growth and Yield}

\subsubsection{Plant Height ( $\mathrm{cm})$ at Flag Leaf Stage}

The effect of salts stress on plant height is shown in Table 4 plant height recorded at flag leaf stage was significantly $(\mathrm{P}<0.05$ (decreased by increasing salinity. Plants grown in all salt treatments were significantly $(\mathrm{P}<0.05)$ shorter than in the control soil treatment. Increasing salinity decreased the plant height. There was larger decrease in plant height at high salinity (EC $10 \mathrm{dS} \cdot \mathrm{m}^{-1}$ ) levels.

\subsubsection{Spike Length $(\mathrm{cm})$}

The effect of salts stress on spike length is shown in Table 5 the plants grown in saline soil treatments had significantly $(\mathrm{P}<0.05)$ shorter spikes than the plants grown in the control soil treatment. Increasing salinity significantly $(\mathrm{P}<0.05)$ decreased the length of spikes. These decreases were greater at high salinity $\left(\mathrm{EC} 10 \mathrm{dS} \cdot \mathrm{m}^{-1}\right)$ level than at low $\left(\right.$ EC $\left.6 \mathrm{dS} \cdot \mathrm{m}^{-1}\right)$ and medium (EC $8 \mathrm{dS} \cdot \mathrm{m}^{-1}$ ) salinity levels. 
Table 3. Physicochemical properties of soil before sowing.

\begin{tabular}{ccc}
\hline S\# & Name & Results \\
\hline 1 & Carbonate & Absent in all samples \\
2 & Soil organic Matter & $0.95 \%$ \\
3 & Soil Textural Class & Silty Clay Loam \\
\hline
\end{tabular}

Table 4. Effect of salts $\left(\mathrm{MgCl}_{2}+\mathrm{CaCl}_{2}+\mathrm{Na}_{2} \mathrm{SO}_{4}\right)$ stress on plant height $(\mathrm{cm})$ recorded at flag stage.

\begin{tabular}{cccc}
\hline Salinity levels EC $\left(\mathrm{dS} \cdot \mathrm{m}^{-1}\right)$ & Classification & Plant height $(\mathrm{cm})$ & Per cent Decrease over Control \\
\hline Control $(2.16)$ & Non-saline & 52.53 & - \\
4.00 & Saline & 46.10 & 12.45 \\
6.00 & Slightly saline & 45.43 & 13.52 \\
8.00 & Moderately saline & 43.20 & 17.61 \\
10.00 & Highly saline & 41.97 & 20.11 \\
& & & 2.6798 \\
\\
S. E. D. & & & $1.2028^{* * *}$ \\
L. S. D. & &
\end{tabular}

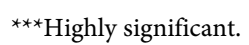

Table 5. Effect of salts $\left(\mathrm{MgCl}_{2}+\mathrm{CaCl}_{2}+\mathrm{Na}_{2} \mathrm{SO}_{4}\right)$ stress on spike length $(\mathrm{cm})$.

\begin{tabular}{cccc}
\hline Salinity levels EC $\left(\mathrm{dS} \cdot \mathrm{m}^{-1}\right)$ & Classification & Spike length $(\mathrm{cm})$ & Per cent Decrease over Control \\
\hline Control $(2.16)$ & Non-saline & 13.767 & - \\
4.00 & Saline & 11.667 & 15.24 \\
6.00 & Slightly saline & 11.533 & 16.23 \\
8.00 & Moderately saline & 10.800 & 21.55 \\
10.00 & Highly saline & 10.500 & 23.73 \\
& & & 0.3949 \\
\\
& S. E. D. & & $0.8798^{* * *}$ \\
& L. S. D. & &
\end{tabular}

${ }^{* * *}$ Highly significant.

\subsubsection{Number of Spikelets Spike ${ }^{-1}$}

The effect of salts stress on number of spikelets spike ${ }^{-1}$ is shown in Table 6. The number of spikelets spike ${ }^{-1}$ was significantly $(\mathrm{P}<0.05)$ decreased by increasing salinity level The Plants grown in saline soil treatments had significantly lower number of spikelets spike $^{-1}$ than the plants grown in the control soil treatment. Increasing salinity had decreasing effect on the number of spikelets spike ${ }^{-1}$. The larger decrease in number of spikelets spike $\mathrm{e}^{-1}$ was recorde on the plants grown at high EC (EC $\left.10 \mathrm{dS} \cdot \mathrm{m}^{-1}\right)$ than at low $\left(\right.$ EC $\left.6 \mathrm{dS} \cdot \mathrm{m}^{-1}\right)$ and medium EC $\left(\right.$ EC $\left.8 \mathrm{dS} \cdot \mathrm{m}^{-1}\right)$ levels.

\subsubsection{Straw Yield (Mg.Plant $\left.{ }^{-1}\right)$}

The effect of salts on straw yield is shown in Table 7. Increasing salts stress significantly $(\mathrm{P}<0.05)$ decreased the straw yield of wheat. The plants grown in saline soil treatments 
Table 6. Effect of salts $\left(\mathrm{MgCl}_{2}+\mathrm{CaCl}_{2}+\mathrm{Na}_{2} \mathrm{SO}_{4}\right)$ Stress on number of spikelets spike ${ }^{-1}$.

\begin{tabular}{|c|c|c|c|}
\hline Salinity Levels EC $\left(\mathrm{dS} \cdot \mathrm{m}^{-1}\right)$ & Classification & Spikelets spike ${ }^{-1}$ & Percent Decrease over Control \\
\hline Control (2.16) & Non-saline & 10.533 & - \\
\hline 4.00 & Saline & 9.633 & 8.54 \\
\hline 6.00 & Slightly saline & 9.033 & 14.24 \\
\hline 8.00 & Moderately saline & 8.733 & 17.09 \\
\hline 10.00 & Highly saline & 8.367 & 20.56 \\
\hline \multicolumn{2}{|l|}{ S. E. D. } & \multicolumn{2}{|r|}{0.2118} \\
\hline \multicolumn{2}{|l|}{ L. S. D. } & \multicolumn{2}{|r|}{$0.4718^{\star * *}$} \\
\hline
\end{tabular}

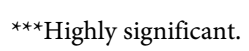

Table 7. Effect of salts $\left(\mathrm{MgCl}_{2}+\mathrm{CaCl}_{2}+\mathrm{Na}_{2} \mathrm{SO}_{4}\right)$ stress on straw yield $\left(\mathrm{mg} \cdot\right.$ plant $\left.^{-1}\right)$.

\begin{tabular}{|c|c|c|c|}
\hline $\begin{array}{c}\text { Salinity levels EC } \\
\left(\mathrm{dS} \cdot \mathrm{m}^{-1}\right)\end{array}$ & Classification & $\begin{array}{c}\text { Straw yield (mg) } \\
\text { spike }^{-1}\end{array}$ & $\begin{array}{c}\text { Per cent Decrease } \\
\text { over Control }\end{array}$ \\
\hline Control (2.16) & Non-saline & 1051.8 & - \\
\hline 4.00 & Saline & 910.2 & 13.46 \\
\hline 6.00 & Slightly saline & 861.5 & 18.10 \\
\hline 8.00 & Moderately saline & 854.5 & 18.74 \\
\hline 10.00 & Highly saline & 839.2 & 20.22 \\
\hline \multicolumn{2}{|c|}{ S. E. D. } & \multicolumn{2}{|c|}{59.4587} \\
\hline \multicolumn{2}{|c|}{ L. S. D. } & \multicolumn{2}{|c|}{$132.4741^{\star}$} \\
\hline
\end{tabular}

${ }^{*}$ Non-significant.

produced significantly lower straw yield than in the control. Increasing salinity decreased the straw yield. The decrease in straw yield was greater at high EC (EC 10 $\left.\mathrm{dS} \cdot \mathrm{m}^{-1}\right)$ than at low $\left(\right.$ EC $\left.6 \mathrm{dS} \cdot \mathrm{m}^{-1}\right)$ and medium EC $\left(\right.$ EC $\left.8 \mathrm{dS} \cdot \mathrm{m}^{-1}\right)$ levels.

\subsubsection{Grain Yield (Mg.Plant ${ }^{-1}$ )}

The effect of salts stress on grain yield is shown in Table 8 . The results revealed that grain yield $\left(\mathrm{mg}\right.$ plant $\left.{ }^{-1}\right)$ decreased significantly $(\mathrm{P}<0.05)$ with increasing salts concentration. The plants grown in salt treatments had significantly lower grain yield than in the control soil treatment. Increasing salinity also decreased grain yield per plant. Compared to the low (EC $6 \mathrm{dS} \cdot \mathrm{m}^{-1}$ ) and medium (EC $8 \mathrm{dS} \cdot \mathrm{m}^{-1}$ ) level, grain yield obtained from high salinity $\left(\mathrm{EC} 10 \mathrm{dS} \cdot \mathrm{m}^{-1}\right.$ ) level remained significantly lower.

\subsubsection{Grain Weight (g)}

The effect of salts stress on 1000 grain weight is shown in Table 9. The results revealed that 1000 grain weight decreased significantly $(\mathrm{P}<0.05)$ with the progressive increase in salts stress. The plants grown in saline soil treatments had significantly lighter grains than in the plants grown in the control soil treatment. The effect of increasing salinity on 1000- 
Table 8. Effect of salts $\left(\mathrm{MgCl}_{2}+\mathrm{CaCl}_{2}+\mathrm{Na}_{2} \mathrm{SO}_{4}\right)$ stress on grain yield (mg.plant $\left.{ }^{-1}\right)$.

\begin{tabular}{|c|c|c|c|}
\hline $\begin{array}{c}\text { Salinity levels EC } \\
\left(\mathrm{dS} \cdot \mathrm{m}^{-1}\right)\end{array}$ & Classification & $\begin{array}{c}\text { Grain yield (mg) } \\
\quad\left(\text { spike }^{-1}\right)\end{array}$ & $\begin{array}{c}\text { Percent Decrease } \\
\text { over Control }\end{array}$ \\
\hline Control (2.16) & Non-saline & 480.40 & - \\
\hline 4.00 & Saline & 355.83 & 25.94 \\
\hline 6.00 & Slightly saline & 231.46 & 51.82 \\
\hline 8.00 & Moderately saline & 219.31 & 54.25 \\
\hline 10.00 & Highly saline & 162.31 & 66.52 \\
\hline \multicolumn{2}{|c|}{ S. E. D. } & \multicolumn{2}{|c|}{40.1995} \\
\hline \multicolumn{2}{|c|}{ L. S. D. } & \multicolumn{2}{|c|}{$89.5645^{\star \star *}$} \\
\hline
\end{tabular}

${ }^{* * *}$ Highly significant.

Table 9. Effect of salts $\left(\mathrm{MgCl}_{2}+\mathrm{CaCl}_{2}+\mathrm{Na}_{2} \mathrm{SO}_{4}\right)$ stress on 1000 grain weight $(\mathrm{g})$.

\begin{tabular}{|c|c|c|c|}
\hline $\begin{array}{l}\text { Salinity levels EC } \\
\left(\mathrm{dS} \cdot \mathrm{m}^{-1}\right)\end{array}$ & Classification & $\begin{array}{l}1000 \text { grain } \\
\text { Weight (g) }\end{array}$ & $\begin{array}{c}\text { Percent Decrease } \\
\text { over Control }\end{array}$ \\
\hline Control (2.16) & Non-saline & 357.10 & - \\
\hline 4.00 & Saline & 228.10 & 36.16 \\
\hline 6.00 & Slightly saline & 149.07 & 58.26 \\
\hline 8.00 & Moderately saline & 130.60 & 63.43 \\
\hline 10.00 & Highly saline & 108.57 & 69.60 \\
\hline \multicolumn{2}{|c|}{ S. E. D. } & \multicolumn{2}{|c|}{33.89} \\
\hline \multicolumn{2}{|c|}{ L. S. D. } & \multicolumn{2}{|c|}{$75.51^{\star * *}$} \\
\hline
\end{tabular}

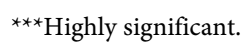

grain weight was decreasing. These grain were significantly lighter in weight at low (EC 6 $\left.\mathrm{dS} \cdot \mathrm{m}^{-1}\right)$, medium $\left(\right.$ EC $\left.8 \mathrm{dS} \cdot \mathrm{m}^{-1}\right)$ and very high at high salinity (EC $\left.10 \mathrm{dS} \cdot \mathrm{m}^{-1}\right)$ levels.

\subsection{Plant Analysis}

\subsection{1. $\mathrm{Na}^{+}, \mathrm{K}^{+}$, and $\mathrm{K}^{+} / \mathrm{Na}^{+}$Ratio in Flag Leaf Sap of Wheat}

The effect of salts stress on $\mathrm{Na}^{+}, \mathrm{K}^{+}$, and $\mathrm{K}^{+} / \mathrm{Na}^{+}$ratio in flag leaf sap of wheat is presented in Tables 10-12. The effect of increasing soil salinity was to increase $\mathrm{Na}^{+}$and decrease $\mathrm{K}^{+}$concentration in the flag leaf sap. This was resulted in lower $\mathrm{K}^{+} / \mathrm{Na}^{+}$ratio. The increase in $\mathrm{Na}^{+}$and decrease in $\mathrm{K}^{+}$were more marked in the flag leaf sap of the plants grown in high salinity treatment than in the control and other sol treatments.

\subsection{2. $\mathrm{Na}^{+}, \mathrm{K}^{+}, \mathrm{Cl}^{-}$and $\mathrm{K}^{+} / \mathrm{Na}^{+}$Ratio in Grains of Wheat}

The effect of salts mixture on ion concentration in the grains of wheat is shown in Tables 13-16. Salinity significantly increased $\mathrm{Cl}^{-}$and $\mathrm{Na}^{+}$but decreased $\mathrm{K}^{+}$and $\mathrm{K}^{+} / \mathrm{Na}^{+}$ ratio contents in the grains at all salinity levels. Plants grown at moderate and high salinity levels had significantly higher $\mathrm{Cl}^{-}$and $\mathrm{Na}^{+}$but lower $\mathrm{K}^{+} / \mathrm{Na}^{+}$ratio than the plants grown at the control and low salinity level. 
Table 10. Effect of salts $\left(\mathrm{MgCl}_{2}+\mathrm{CaCl}_{2}+\mathrm{Na}_{2} \mathrm{SO}_{4}\right)$ stress on $\mathrm{Na}^{+}(\%)$ in flag leaf sap of wheat.

\begin{tabular}{|c|c|c|c|}
\hline Salinity levels EC $\left(\mathrm{dS} \cdot \mathrm{m}^{-1}\right)$ & Classification & $\mathrm{Na}^{+}(\%)$ & Per cent Decrease over Control \\
\hline Control (2.16) & Non-saline & 0.28333 & - \\
\hline 4.00 & Saline & 0.34333 & 21.18 \\
\hline 6.00 & Slightly saline & 0.41000 & 44.70 \\
\hline 8.00 & Moderately saline & 0.45333 & 60.00 \\
\hline 10.00 & Highly saline & 0.53667 & 89.41 \\
\hline \multicolumn{2}{|l|}{ S. E. D. } & \multicolumn{2}{|r|}{0.0313} \\
\hline \multicolumn{2}{|l|}{ L. S. D. } & \multicolumn{2}{|r|}{$0.0697^{* * *}$} \\
\hline
\end{tabular}

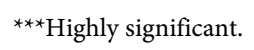

Table 11. Effect of salts $\left(\mathrm{MgCl}_{2}+\mathrm{CaCl}_{2}+\mathrm{Na}_{2} \mathrm{SO}_{4}\right)$ stress on $\mathrm{K}^{+}(\%)$ in flag leaf sap of wheat.

\begin{tabular}{cccc}
\hline Salinity levels EC $\left(\mathrm{dS} \cdot \mathrm{m}^{-1}\right)$ & Classification & $\mathrm{K}^{+}(\%)$ & Per cent Decrease over Control \\
\hline Control $(2.16)$ & Non-saline & 0.7333 & - \\
4.00 & Saline & 0.6500 & 11.36 \\
6.00 & Slightly saline & 0.4733 & 35.46 \\
8.00 & Moderately saline & 0.4133 & 43.64 \\
10.00 & Highly saline & 0.3533 & 51.83 \\
& & & 0.1192 \\
& S. E. D. & & $0.2655^{\star}$ \\
\hline
\end{tabular}

${ }^{\star}$ Non-significant.

Table 12. Effect of salts $\left(\mathrm{MgCl}_{2}+\mathrm{CaCl}_{2}+\mathrm{Na}_{2} \mathrm{SO}_{4}\right)$ stress on $\mathrm{K}^{+} / \mathrm{Na}^{+}$in flag leaf sap of wheat.

\begin{tabular}{|c|c|c|c|}
\hline Salinity levels EC $\left(\mathrm{dS} \cdot \mathrm{m}^{-1}\right)$ & Classification & $\mathrm{K}^{+} / \mathrm{Na}^{+}$ & Per cent Decrease over Control \\
\hline Control (2.16) & Non-saline & 2.6167 & - \\
\hline 4.00 & Saline & 1.8700 & 28.54 \\
\hline 6.00 & Slightly saline & 1.1667 & 55.42 \\
\hline 8.00 & Moderately saline & 0.9300 & 64.46 \\
\hline 10.00 & Highly saline & 0.6600 & 74.78 \\
\hline \multicolumn{2}{|l|}{ S. E. D. } & \multicolumn{2}{|r|}{0.3286} \\
\hline \multicolumn{2}{|l|}{ L. S. D. } & \multicolumn{2}{|r|}{$0.7322^{\star *}$} \\
\hline
\end{tabular}

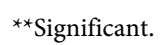

\subsection{3. $\mathrm{Na}^{+}, \mathrm{K}^{+}, \mathrm{Cl}^{-}$and $\mathrm{K}^{+} / \mathrm{Na}^{+}$Ratio in Wheat Straw}

The effects of different salinity levels on ion concentrations in the straw are shown in the Tables 17-20. Salinity significantly $(\mathrm{P}<0.05)$ increased the toxic ions $\left(\mathrm{Na}^{+}\right.$and $\left.\mathrm{Cl}^{-}\right)$ and decreased the concentration of $\mathrm{K}^{+}$and $\mathrm{K}^{+} / \mathrm{Na}^{+}$ratio in the straw at all levels. At high salinity level plants accumulated more $\mathrm{Na}^{+}$and $\mathrm{Cl}^{-}$but less $\mathrm{K}^{+}$and hence they ex habited lower $\mathrm{K}^{+} / \mathrm{Na}^{+}$in their straw. 
Table 13. Effect of salts $\left(\mathrm{MgCl}_{2}+\mathrm{CaCl}_{2}+\mathrm{Na}_{2} \mathrm{SO}_{4}\right)$ stress on $\mathrm{Na}^{+}(\%)$ in grain of wheat.

\begin{tabular}{cccc}
\hline Salinity levels EC $\left(\mathrm{dS} \cdot \mathrm{m}^{-1}\right)$ & Classification & $\mathrm{Na}^{+}(\%)$ & Per cent Increase over Control \\
\hline Control $(2.16)$ & Non-saline & 0.3733 & - \\
4.00 & Saline & 0.5033 & 34.82 \\
6.00 & Slightly saline & 0.7033 & 88.40 \\
8.00 & Moderately saline & 0.9033 & 141.97 \\
10.00 & Highly saline & 1.1100 & 197.34 \\
& & & 0.0549 \\
& S. E. D. & & $0.1223^{* * *}$ \\
\hline
\end{tabular}

${ }^{* * *}$ Highly significant.

Table 14. Effect of salts $\left(\mathrm{MgCl}_{2}+\mathrm{CaCl}_{2}+\mathrm{Na}_{2} \mathrm{SO}_{4}\right)$ stress on $\mathrm{K}^{+}(\%)$ in grains of wheat.

\begin{tabular}{cccc}
\hline Salinity levels EC $\left(\mathrm{dS} \cdot \mathrm{m}^{-1}\right)$ & Classification & $\mathrm{K}^{+}(\%)$ & Per cent Decrease over Control \\
\hline Control $(2.16)$ & Non-saline & 0.35333 & - \\
4.00 & Saline & 0.25667 & 27.36 \\
6.00 & Slightly saline & 0.22000 & 37.74 \\
8.00 & Moderately saline & 0.16333 & 35.78 \\
10.00 & Highly saline & 0.11667 & 66.98 \\
& & & 0.0300 \\
& S. E. D. & & $0.0668^{* * *}$ \\
\hline
\end{tabular}

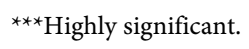

Table 15. Effect of salts $\left(\mathrm{MgCl}_{2}+\mathrm{CaCl}_{2}+\mathrm{Na}_{2} \mathrm{SO}_{4}\right)$ stress on $\mathrm{K}^{+} / \mathrm{Na}^{+}$in grains of wheat.

\begin{tabular}{cccc}
\hline Salinity levels EC $\left(\mathrm{dS} \cdot \mathrm{m}^{-1}\right)$ & Classification & $\mathrm{K}^{+} / \mathrm{Na}^{+}$ & Per cent Decrease over Control \\
\hline Control $(2.16)$ & Non-saline & 0.9440 & - \\
4.00 & Saline & 0.5092 & 46.07 \\
6.00 & Slightly saline & 0.3114 & 67.01 \\
8.00 & Moderately saline & 0.1821 & 80.71 \\
10.00 & Highly saline & 0.1038 & 89.01 \\
& & & 0.0489 \\
& S. E. D. & & $0.1089^{* * *}$ \\
\hline
\end{tabular}

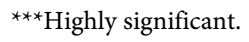

\subsection{4. $\mathrm{Ca}^{2+}$ and $\mathrm{Mg}^{2+}$ Content in Grains and Wheat Straw}

The effect of salts stress on $\mathrm{Ca}^{2+}$ and $\mathrm{Mg}^{2+}$ contents in grains and straw of wheat are shown in the Tables 21-24. The results indicated that with the increasing concentration of soluble salts in soil (Table 1 , Table 2) the concentration of $\mathrm{Ca}^{2}$ and $\mathrm{Mg}^{2+}$ increased both in grains and straw of wheat. Plants in high salinity treatments accumulated more $\mathrm{Ca}^{2+}$ and $\mathrm{Mg}^{2+}$ than in other soil treatments.

The soil used in this experiment was sandy clay with $37.5 \%$ clay and $0.95 \%$ organic matter. When this soil was treated with salts it showed properties typical to those of saline soils of Sindh (Ghafoor, 2004). 
Table 16. Effect of salts $\left(\mathrm{MgCl}_{2}+\mathrm{CaCl}_{2}+\mathrm{Na}_{2} \mathrm{SO}_{4}\right)$ stress on $\mathrm{Cl}^{-}\left(\right.$meq $\left.100 \mathrm{~g}^{-1}\right)$ in grains of wheat.

\begin{tabular}{|c|c|c|c|}
\hline $\begin{array}{c}\text { Salinity levels EC } \\
\left(\mathrm{dS} \cdot \mathrm{m}^{-1}\right)\end{array}$ & Classification & $\begin{array}{c}\mathrm{Cl}^{-} \\
\left(\text {meq } 100 \mathrm{~g}^{-1}\right)\end{array}$ & $\begin{array}{c}\text { Per cent Increase } \\
\text { over Control }\end{array}$ \\
\hline Control (2.16) & Non-saline & 50.00 & - \\
\hline 4.00 & Saline & 81.67 & 63.36 \\
\hline 6.00 & Slightly saline & 92.33 & 84.66 \\
\hline 8.00 & Moderately saline & 102.33 & 104.66 \\
\hline 10.00 & Highly saline & 115.67 & 131.34 \\
\hline \multicolumn{2}{|c|}{ S. E. D. } & \multicolumn{2}{|c|}{13.9044} \\
\hline \multicolumn{2}{|c|}{ L. S. D. } & \multicolumn{2}{|c|}{$30.9790^{* * *}$} \\
\hline
\end{tabular}

${ }^{* * *}$ Highly significant.

Table 17. Effect of salts $\left(\mathrm{MgCl}_{2}+\mathrm{CaCl}_{2}+\mathrm{Na}_{2} \mathrm{SO}_{4}\right)$ stress on $\mathrm{Na}^{+}(\%)$ in wheat straw.

\begin{tabular}{cccc}
\hline Salinity levels EC $\left(\mathrm{dS} \cdot \mathrm{m}^{-1}\right)$ & Classification & $\mathrm{Na}^{+}(\%)$ & Per cent Increase over Control \\
\hline Control $(2.16)$ & Non-saline & 0.4900 & - \\
4.00 & Saline & 0.6733 & 37.40 \\
6.00 & Slightly saline & 0.7700 & 57.14 \\
8.00 & Moderately saline & 1.1333 & 131.28 \\
10.00 & Highly saline & 1.3833 & 182.30 \\
& & & 0.0848 \\
& S. E. D. & & $0.1891^{* * *}$ \\
\hline
\end{tabular}

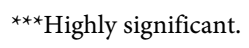

Table 18. Effect of salts $\left(\mathrm{MgCl}_{2}+\mathrm{CaCl}_{2}+\mathrm{Na}_{2} \mathrm{SO}_{4}\right)$ stress on $\mathrm{K}^{+}(\%)$ in wheat straw.

\begin{tabular}{cccc}
\hline Salinity levels EC $\left(\mathrm{dS} \cdot \mathrm{m}^{-1}\right)$ & Classification & $\mathrm{K}^{+}(\%)$ & Per cent Decrease over Control \\
\hline Control $(2.16)$ & Non-saline & 1.7000 & - \\
4.00 & Saline & 1.2333 & 8.14 \\
6.00 & Slightly saline & 1.1467 & 20.46 \\
8.00 & Moderately saline & 1.0700 & 29.46 \\
10.00 & Highly saline & 0.9267 & 32.53 \\
& & & 0.0870 \\
& S. E. D. & & $0.1951^{* * *}$ \\
\hline
\end{tabular}

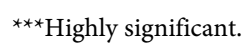

The results obtained in this experiment showed that salinity had adverse effects on almost all growth and yield parameters. The effects of high salinity on soot height (Table 3), spike length (Table 4), number of spilelets spike ${ }^{-1}$ (Table 5), straw yield (Table 6), grain yield (Table 7) and 1000 grain weight (Table 8) were greater than low and medium salinity. The plants grown at high salinity level were $20.56 \%$ smaller in height, produced $23.73 \%$ smaller spikes, showed $20.56 \%$ fewer spikelets. High salinity 
Table 19. Effect of salts $\left(\mathrm{MgCl}_{2}+\mathrm{CaCl}_{2}+\mathrm{Na}_{2} \mathrm{SO}_{4}\right)$ stress on $\mathrm{K}^{+} / \mathrm{Na}^{+}$in wheat straw.

\begin{tabular}{cccc}
\hline Salinity levels EC $\left(\mathrm{dS} \cdot \mathrm{m}^{-1}\right)$ & Classification & $\mathrm{K}^{+} / \mathrm{Na}^{+}$ & Per cent Decrease over Control \\
\hline Control $(2.16)$ & Non-saline & 3.0874 & - \\
4.00 & Saline & 2.1039 & 31.86 \\
6.00 & Slightly saline & 1.5828 & 48.73 \\
8.00 & Moderately saline & 0.9622 & 68.83 \\
10.00 & Highly saline & 0.7410 & 76.00 \\
& & & 0.3435 \\
& & & $0.7653^{* * *}$ \\
\hline
\end{tabular}

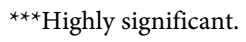

Table 20. Effect of salts $\left(\mathrm{MgCl}_{2}+\mathrm{CaCl}_{2}+\mathrm{Na}_{2} \mathrm{SO}_{4}\right)$ stress on $\mathrm{Cl}^{-}\left(\right.$meq $\left.100 \mathrm{~g}^{-1}\right)$ in wheat straw.

\begin{tabular}{|c|c|c|c|}
\hline $\begin{array}{l}\text { Salinity levels EC } \\
\left(\mathrm{dS} \cdot \mathrm{m}^{-1}\right)\end{array}$ & Classification & $\begin{array}{c}\mathrm{Cl}^{-} \\
\left(\text {meq } 100 \mathrm{~g}^{-1}\right)\end{array}$ & $\begin{array}{l}\text { Per cent Increase } \\
\text { over Control }\end{array}$ \\
\hline Control (2.16) & Non-saline & 75.00 & - \\
\hline 4.00 & Saline & 91.33 & 21.77 \\
\hline 6.00 & Slightly saline & 113.00 & 50.66 \\
\hline 8.00 & Moderately saline & 125.67 & 67.56 \\
\hline 10.00 & Highly saline & 131.00 & 74.66 \\
\hline \multicolumn{2}{|c|}{ S. E. D. } & \multicolumn{2}{|c|}{7.8951} \\
\hline \multicolumn{2}{|c|}{ L. S. D. } & \multicolumn{2}{|c|}{$17.5903^{* * *}$} \\
\hline
\end{tabular}

${ }^{* * *}$ Highly significant.

Table 21. Effect of salts $\left(\mathrm{MgCl}_{2}+\mathrm{CaCl}_{2}+\mathrm{Na}_{2} \mathrm{SO}_{4}\right)$ stress on $\mathrm{Ca}^{2+}(\%)$ in grains of wheat.

\begin{tabular}{cccc}
\hline Salinity levels EC $\left(\mathrm{dS} \cdot \mathrm{m}^{-1}\right)$ & Classification & $\mathrm{Ca}^{2+}(\%)$ & Per cent Increase over Control \\
\hline Control (2.16) & Non-saline & 0.8333 & - \\
4.00 & Saline & 1.0733 & 28.80 \\
6.00 & Slightly saline & 1.1100 & 33.21 \\
8.00 & Moderately saline & 1.1433 & 37.20 \\
10.00 & Highly saline & 1.1833 & 42.00 \\
& & & 0.0816 \\
& S. E. D. & & $0.1818^{*}$ \\
\hline
\end{tabular}

${ }^{*}$ Non-significant.

decreased straw yield by $20.22 \%$, grain yield by $66.52 \%$ other workers [18] [19] [20] [21] have also pointed out that the yield of wheat crop decreased significantly with increasing salinity levels. The decrease in grain yield under highly saline soil treatments was due to the fewer tillers, lighter grains. It has also been reported by others workers 
Table 22. Effect of salts $\left(\mathrm{MgCl}_{2}+\mathrm{CaCl}_{2}+\mathrm{Na}_{2} \mathrm{SO}_{4}\right)$ stress on $\mathrm{Mg}^{2+}(\%)$ in grains of wheat.

\begin{tabular}{|c|c|c|c|}
\hline Salinity levels EC $\left(\mathrm{dS} \cdot \mathrm{m}^{-1}\right)$ & Classification & $\mathrm{Mg}^{2+}(\%)$ & Per cent Increase over Control \\
\hline Control (2.16) & Non-saline & 1.2867 & - \\
\hline 4.00 & Saline & 1.4267 & 10.88 \\
\hline 6.00 & Slightly saline & 1.5600 & 21.24 \\
\hline 8.00 & Moderately saline & 1.6667 & 29.53 \\
\hline 10.00 & Highly saline & 1.8167 & 41.19 \\
\hline \multicolumn{2}{|l|}{ S. E. D. } & \multicolumn{2}{|r|}{0.0423} \\
\hline \multicolumn{2}{|l|}{ L. S. D. } & \multicolumn{2}{|r|}{$0.0944^{* * *}$} \\
\hline
\end{tabular}

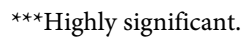

Table 23. Effect of salts $\left(\mathrm{MgCl}_{2}+\mathrm{CaCl}_{2}+\mathrm{Na}_{2} \mathrm{SO}_{4}\right)$ stress on $\mathrm{Ca}^{2+}(\%)$ in wheat straw.

\begin{tabular}{|c|c|c|c|}
\hline Salinity levels EC $\left(\mathrm{dS} \cdot \mathrm{m}^{-1}\right)$ & Classification & $\mathrm{Ca}^{2+}(\%)$ & Per cent Increase over Control \\
\hline Control (2.16) & Non-saline & 0.9733 & - \\
\hline 4.00 & Saline & 1.1067 & 13.71 \\
\hline 6.00 & Slightly saline & 1.1600 & 19.18 \\
\hline 8.00 & Moderately saline & 1.2400 & 27.40 \\
\hline 10.00 & Highly saline & 1.2933 & 32.88 \\
\hline \multicolumn{2}{|l|}{ S. E. D. } & \multicolumn{2}{|r|}{0.1194} \\
\hline \multicolumn{2}{|l|}{ L. S. D. } & \multicolumn{2}{|r|}{ NS } \\
\hline
\end{tabular}

Table 24. Effect of salts $\left(\mathrm{MgCl}_{2}+\mathrm{CaCl}_{2}+\mathrm{Na}_{2} \mathrm{SO}_{4}\right)$ stress on $\mathrm{Mg}^{2+}(\%)$ in wheat straw.

\begin{tabular}{cccc}
\hline Salinity levels EC $\left(\mathrm{dS} \cdot \mathrm{m}^{-1}\right)$ & Classification & $\mathbf{M g}^{2+}(\%)$ & Per cent Increase over Control \\
\hline Control $(2.16)$ & Non-saline & 1.2933 & - \\
4.00 & Saline & 1.9667 & 52.07 \\
6.00 & Slightly saline & 2.3300 & 80.16 \\
8.00 & Moderately saline & 2.5200 & 94.85 \\
10.00 & Highly saline & 2.9100 & 125.00 \\
& & & 0.3521 \\
& S. E. D. & & $\mathbf{0 . 7 8 4 6 *}$ \\
\hline
\end{tabular}

${ }^{*}$ Non-significant.

[20] that decreased tillering is the main cause for lower crop yield in salt-affected soils of arid and semi arid regions.

The greater effects of salinity on plants were associated with larger effects on ions (Tables 9-23). As was expected, the effects of salinity on plants was to increase $\mathrm{Na}^{+}$, $\mathrm{Cl}^{-}, \mathrm{Ca}^{2+}$ and $\mathrm{Mg}^{2+}$ and decrease $\mathrm{K}^{+}$and $\mathrm{K}^{+} / \mathrm{Na}^{+}$ratio compared to control plants. The increase in $\mathrm{Na}^{+}, \mathrm{Cl}^{-}, \mathrm{Ca}^{2+}$ and $\mathrm{Mg}^{2+}$ contents may be attributed to the increase amount of sodium, calcium and magnesium in soil solution due to the addition of salts $\left(\mathrm{MgCl}_{2}\right.$ $+\mathrm{CaCl}_{2}+\mathrm{Na}_{2} \mathrm{SO}_{4}$ ) when soils were prepared. Similar effects of salinity on wheat plants for ions content have been reported by many workers [22] [23] [24] [25] [26]. 


\section{Conclusions}

A pot experiment was conducted in the wire-house of the department of Soil Science, Sindh Agriculture University Tando Jam to see the effects of salts stress on the growth and yield of wheat (Cv. Inqalab).

The soil used in the experiment was clay loam in texture, alkaline in reaction $(\mathrm{pH}>$ 7.0 ), moderate in organic matter $(0.95 \%)$. The soil was artificially salinized to different salinity levels i.e. ECe 2.16, 4.0, 6.0, 8.0 and $10.0 \mathrm{dS} \cdot \mathrm{m}^{-1}$ with different salts $\left(\mathrm{MgCl}_{2}+\right.$ $\mathrm{CaCl}_{2}+\mathrm{Na}_{2} \mathrm{SO}_{4}$ ). The plant data were subjected to statistical analysis.

Following key points have been observed during this study.

1) Increasing salinity increased the ECe, $\mathrm{Na}^{+} \mathrm{Ca}^{2+}, \mathrm{Mg}^{2+}$ and $\mathrm{Cl}^{-}$content and decreased the $\mathrm{K}^{+}$, SAR and ESP values in the soil.

2) Increasing salinity significantly decreased plant height, spike length, number of spikelets Spike ${ }^{-1}, 1000$ grain weight, and straw and grain yields plant ${ }^{-1}$. Increasing salinity significantly increased $\mathrm{Na}^{+}$concentration but decreased $\mathrm{K}^{+}$concentration and $\mathrm{K}^{+} / \mathrm{Na}^{+}$ratio in the flag leaf sap.

3) Increasing salinity increased $\mathrm{Na}^{+}, \mathrm{Ca}^{2+}, \mathrm{Mg}^{2+}$ and $\mathrm{Cl}^{-}$content while decreased $\mathrm{K}^{+}$ and $\mathrm{K}^{+} / \mathrm{Na}^{+}$ratio in straw and grains.

4) Effect of salts $\left(\mathrm{MgCl}_{2}+\mathrm{CaCl}_{2}+\mathrm{Na}_{2} \mathrm{SO}_{4}\right)$ stress on almost all parameters was significant.

It was concluded from the present study that salts stress $\left(\mathrm{MgCl}_{2}+\mathrm{CaCl}_{2}+\mathrm{Na}_{2} \mathrm{SO}_{4}\right)$ adversely affects the growth and yield of cultivar Inqalab. Due to the osmotic and ionic toxicity effects, its yield immediately decreased as salinity level increased.

\section{References}

[1] Munns, R. and Tester, M. (2008) Mechanisms of Salinity Tolerance. Annual Review of Plant Biology, 59, 651-681. http://dx.doi.org/10.1146/annurev.arplant.59.032607.092911

[2] NFDC (2003) Fertilzers and Their Use in Pakistan. 3rd Edition, NFDC, Islamabad.

[3] Atlassi, P.V., Nabipour, M. and Meskarbashee, M. (2009) Effect of Salt Stress on Chlorophyll Content, Fluorescence, $\mathrm{Na}^{+}$and $\mathrm{K}^{+}$Ions Content in Rape Plants (Brassica napus L.). Asian Journal of Agriculture, 3, 28-37. http://dx.doi.org/10.3923/ajar.2009.28.37

[4] Akram, M., Hussain, M., Akhtar, S. and Rasule, E. (2002) Impact of $\mathrm{NaCl}$ Salinity on Yield Components of Some Wheat Accessions/Varieties. International Journal of Agriculture \& Biology.

[5] Qados, A. and Amira, M.S. (2011) Effect of Salt Stress on Plant Growth and Metabolism of Bean Plant Vicia faba (L.). Journal of the Saudi Society of Agricultural Sciences, 10, 7-15. http://dx.doi.org/10.1016/j.jssas.2010.06.002

[6] Zheng, Y., Xu, X., Li, Z. and Yang, X. (2009) Differential Responses of Grain Yield and Quality to Euphytica, Salinity between Wheat Cultivars. Seeds Sciences and Biotechnology, 3, 40-43.

[7] Zhao, G.Q., Ma, B.L. and Ren, C.Z. (2007) Growth, Gas Exchange, Chlorophyll Fluorescence and Ion Content of Naked Oat in Response to Salinity. Crop Science, 47, 123-131. http://dx.doi.org/10.2135/cropsci2006.06.0371

[8] Siler, B., Misic, D., Filipovic, B., Popovic, Z., Cvetic, T. and Mijovic, A. (2007) Effects of Salinity on in Vitro Growth and Photosynthesis of Common Centaury (Centaurium erythraea 
Rafn.). Archives of Biological Sciences, 59, 129-134.

http://dx.doi.org/10.2298/ABS0702129S

[9] Kramer, U. and Amtmann, A. (2012) Salt Stress Signals Shape the Plant Root Carlos S Galvan-Ampudia and Christa Testerink. Plant Biology, 14, 296-302.

[10] Sultana, N., Ikeda, T. and Itoh, R. (2000) Effect of NaCl Salinity on Photosynthesis and Dry Matter Accumulation in Developing Rice Grains. Environmental and Experimental Botany, 42, 211-220. http://dx.doi.org/10.1016/S0098-8472(99)00035-0

[11] Rowell, D.L. (1994) The Preparation of Saturation Extract and the Analysis of Soil Salinity and Sodicity. In: Rowell, D.L. Ed., Soil Science Methods and Applications, London.

[12] Gorham, J. (1994) Slat Tolerance of Plants. Science Progress, Oxford, 273-285.

[13] Bridges, G.J., Dubsocovsky, J., Dvorak, J., Holington, P.A., Luo, M.C. and Khan, J.A. (1997) Genetic Analysis of Trait for Enhances K/Na Distribution in Wheat. New Physiologist, 137, 109-116.

[14] BARD (1990) Methods Manuals Soils.

[15] Kanwar, J.S. and Chopra, S.L. (1959) Practical Agriculture Chemistry. S. Chand and Co., New Dehli, 130-131.

[16] Jackson, M.L. (1958) Soil Chemical Analysis. Prentice Hall Inc., Englewood Chiffs, 213-214.

[17] USSl Staff (1954) Diagnosis and Improvement of Saline and Alkali Soils. USDA, US Government Printing Office, Washington DC.

[18] Mazher, A.M.A., El-Quesni, E.M.F. and Farahat, M.M. (2007) Responses of Ornamental and Woody Trees to Salinity. World Journal of Agricultural Sciences, 3, 386-395.

[19] Memon, S.A., Hou, X. and Wang, L.J. (2010) Morphological Analysis of Salt Stress Response of Pak Choi. Electronic Journal of Environmental, Agricultural and Food Chemistry, 9, 248-254.

[20] Arif, M. and Swati, M.S. (2002) Yield Components as Affected by Salt Stress. Sarhad Journal of Agriculture, 18, 389-391.

[21] Al-Uqaili, J.K. (2003) Potential of Using Saline Water for Wheat Production in Iraq. Emirates Journal of Agricultural. Science, 15, 36-43.

[22] Khan, M.A., Shirazi, M.U., Khan, M.A., Mujtaba, S.M., Islam, E., Mumtaz, S., Shereen, A., Ansari, R.U. and Ashraf, M.Y. (2009) Role of Proline, K/Na Ratio and Chlorophyll Content in Salt Tolerance of Wheat (Triticum aestivum L.). Pakistan Journal of Botany, 41, 633-638.

[23] Hendawy, S., Elhua, Y., Yakout, G.M., Awad, A.M., Hafiz, S.E. and Schmidhalter, U. (2005) Evaluating Salt Tolerance of Wheat Genotypes Using Multiple Parameters. European Journal of Agronomy, 22, 243-253. http://dx.doi.org/10.1016/j.eja.2004.03.002

[24] Sharma, P.C. (2003) Salt Tolerance of Indian Mustard: Factor Affecting Growth and Yield. Indian Journal of Physiology and Pharmacology, 368-372.

[25] Wilson. C., Read, J. and Abo-Kaseem, E. (2002) Effect of Mixed Salt Salinity on Growth and Ion Uptake of Quinon and a Wheat Variety. Journal of Plant Nutrition, 25, 2689-2704. http://dx.doi.org/10.1081/PLN-120015532

[26] Taffouo, V.D., Kouamou, J.K., Ngalangue, L.M.T., Ndjeudji, B.A.N. and Akoa, A. (2009) Effects of Salinity Stress on Growth, Ions Partitioning and Yield of Some Cowpea (Vigna ungiuculata L., Walp) Cultivars. International Journal of Botany, 5, 135-143.

http://dx.doi.org/10.3923/ijb.2009.135.143 
Submit or recommend next manuscript to SCIRP and we will provide best service for you:

Accepting pre-submission inquiries through Email, Facebook, LinkedIn, Twitter, etc. A wide selection of journals (inclusive of 9 subjects, more than 200 journals)

Providing 24-hour high-quality service

User-friendly online submission system

Fair and swift peer-review system

Efficient typesetting and proofreading procedure

Display of the result of downloads and visits, as well as the number of cited articles

Maximum dissemination of your research work

Submit your manuscript at: http://papersubmission.scirp.org/

Or contact ajps@scirp.org 